\title{
Pengaruh DAR dan Ukuran Perusahaan Terhadap ROA Perusahaan yang Terdaftar Di LQ45 Pada BEI
}

\author{
Meiliani Luckieta' $^{1}$, Ali Amran², Doni Purnama Alamsyah ${ }^{3}$ \\ ${ }^{1}$ Sekolah Tinggi Ilmu Ekonomi (STIE) Harapan Bangsa, Indonesia \\ e-mail: ${ }^{1}$ meiliani@ithb.ac.id \\ ${ }^{2}$ Universitas ARS Internasional, Indonesia \\ email: ªli.alq@ars.ac.id \\ ${ }^{3}$ Bina Nusantara University, Indonesia \\ email: ${ }^{3}$ doni.syah@binus.ac.id

\begin{tabular}{ccc}
\hline Diterima & Direvisi & Disetujui \\
$02-11-2020$ & $04-02-2021$ & $11-02-2021$ \\
\hline
\end{tabular}

\begin{abstract}
Abstrak - Penelitian ini dilaksanakan dengan tujuan untuk menganalisis adanya pengaruh dari Struktur Modal (DAR) dan Ukuran Perusahaan terhadap profitabilitas perusahaan (ROA) yang terdaftar di LQ45 pada BEI sehingga dapat memberikan gambaran dan pemahaman yang mendalam untuk digunakan para investor dan pelaku bisnis dalam upaya meningkatkan profitabilitas perusahaannya. Metode yang digunakan adalah metode verifikatif. Variabel yang digunakan adalah variabel Struktur Modal (DAR) dan ukuran perusahaan sebagai variabel independent, variabel profitabilitas perusahaan (ROA) sebagai variabel dependent. Sumber data yang digunakan adalah data sekunder berupa laporan keuangan 23 perusahaan yang aktif selama periode 2013 - 2017 dan terdaftar di LQ 45 Bursa Efek Indonesia. Sedangkan Teknik pengumpulan data yang digunakan yaitu dengan metode dokumentasi, berdasarkan kriteria-kriteria yang telah diseleksi diperoleh 23 perusahaan sebagai sampel penelitian. Sumber data berasal dari Laporan Keuangan Perusahaan yang terdaftar di LQ 45 Bursa Efek Indonesia periode 2013 - 2017. Teknik analisis data menggunakan Analisis Regresi Linier Sederhana dengan Program SPSS 20. Hasil penelitian ini membuktikan secara parsial bahwa Struktur Modal berpengaruh secara positif dan signifikan terhadap Profitabilitas Ukuran Perusahaan berpengaruh terhadap Profitabilitas Struktur Modal dan Ukuran Perusahaan secara bersama-sama berpengaruh terhadap Profitabilitas
\end{abstract}

Kata Kunci: Ukuran Perusahaan, ROA, DAR.

Abstract - This research was conducted with the aim of analyzing the influence of Capital Structure (DAR) and Company Size on company profitability (ROA) listed in LQ45 on the IDX so that it can provide an in-depth overview and understanding for investors and business people to use in an effort to increase the profitability of their companies. The method used is the verification method. The variables used are the capital structure variable (DAR) and company size as the independent variable, the company profitability variable (ROA) as the dependent variable. The data source used is secondary data in the form of financial statements of 23 companies that were active during the 2013 - 2017 period and listed on the LQ 45 Indonesia Stock Exchange. While the data collection technique used is the documentation method, based on the selected criteria obtained by 23 companies as the research sample. The data source comes from the Company's Financial Statements listed on the LQ 45 Indonesia Stock Exchange for the period 2013 - 2017. The data analysis technique uses Simple Linear Regression Analysis with the SPSS 20 Program. The results of this study prove partially that the Capital Structure has a positive and significant effect on Size Profitability. Companies have an effect on the Profitability of Capital Structure and Company Size together have an effect on Profitability.

Keywords: Company Size, ROA, DAR.

\section{PENDAHULUAN}

Kondisi fisik perusahaan bukan merupakan satu-satunya indikator untuk mengetahui besar kecil dan sehat tidaknya suatu perusahaan, tetapi dapat juga dilihat dari sisi keuangannya (Suryandani, 2018). Hal ini dikarenakan keuangan merupakan salah satu unsur yang dapat mengevaluasi apakah kinerja perusahaan sudah dapat berjalan dengan benar sesuai dengan tujuan perusahaan dan kebijakan yang dilakukan suatu perusahaan sudah tepat (Astuti, 2019). Analisis kerja keuangan pada dasarnya dibuat untuk dapat melihat prospek dan resiko perusahaan (Riyadi, 2018). Dimana prospek perusahaan salah satunya dapat dilihat pada tingkat keuntungan (Dewi \& Candradewi, 2018). Semua perusahaan didirikan dengan tujuan untuk 
mencapai profitabilitas, sehingga dapat memberikan kemakmuran dan return bagi pemilik atau pemegang saham perusahaan (Jaenudin \& Jeni, 2012) Profitabilitas merupakan kemampuan perusahaan sehingga dapat memberikan kemakmuran bagi pemegang saham melalui semua kemampuan dan sumber daya yang ada (Mudawamah et al., 2018). Dari hasil penelitian-penelitian sebelumnya, terdapat banyak faktor yang mempengaruhi profitabilitas perusahaan diantaranya struktur modal dan ukuran perusahaan (Maryanti, 2016).

Fenomena pada perusahaan secara umum jika ratio profitabilitas cenderung naik, maka ratio tingkat hutang akan cenderung turun (Supardi et al., 2018). Perusahaan yang mempunyai tingkat profitabilitas yang tinggi dipercaya akan memiliki lebih banyak dana internal sehingga dalam komposisi struktur modal, penggunaan modal sendiri akan otomatis lebih besar daripada penggunaan hutang, dengan demikian maka ratio struktur modal akan semakin lebih kecil. (Amelia et al., 2019). Tingkat profitabilitas yang tinggi dapat dicapai dengan struktur modal yang optimal.(Rahimian, 2016). Struktur modal sendiri merupakan kunci perbaikan tingkat produktivitas dan kinerja perusahaan (Gill et al., 2011). Hal tersebut menjelaskan makna dari struktur modal pada perubahan positif dari profitabilitas perusahaan (Kartikasari \& Merianti, 2016).

Ukuran perusahaan merupakan gambaran perusahaan yang menunjukkan keberhasilan perusahan yang dapat terlihat dari total asset yang dimiliki oleh perusahaan (Mare tha, 2016). Besar kecilnya ukuran perusahaan digambarkan dengan kepemilikan total aktiva, jumlah penjualan, rata-rata total penjualan dan rata-rata total aktiva (Pervan, 2012). Semakin besar tingkat ukuran perusahaan maka akan semakin tinggi pula tingkat utang yang digunakan dengan tujuan untuk mengembangkan ukuran perusahaan (Maretha, 2016). Faktor-faktor utama yang dianggap dapat mempengaruhi ukuran perusahaan diantaranya besarnya total aktiva, besarnya hasil penjualan, dan besarnya kapitalisasi pasar (Supardi et al., 2018). Perusahaan yang mempunyai ukuran perusahaan lebih besar, maka secara otomatis memiliki akses yang lebih besar untuk mendapatkan sumber dana dari berbagai sumber bahkan dapat memperoleh pinjaman dari kreditur dengan lebih mudah (Pongrangga, 2015). Perusahaan dengan ukuran yang lebih besar juga dianggap memiliki tingkat profitabilitas lebih baik untuk dapat memenangkan persaingan pasar (Suryandani, 2018).

Adapun kondisi dari semua perusahaan aktif yang terdaftar di Bursa Efek Indonesia periode 20132017 cenderung berfluktuatif searah dan positif untuk ROA dimana pada bulan Juni 2013 turun, Desember 2014 naik dan Juni 2014 turun, dan begitu seterusnya sampai Juni 2017 turun kembali. Sedangkan untuk kondisi dari DAR dengan periode yang sama terlihat hampir semua perusahaan mengalami fluktuasi yang searah dan positif, tetapi juga terlihat ada yang mengalami peningkatan maupun penurunan. Sama halnya dengan ukuran perusahaan, dalam periode yang sama terlihat hampir semua perusahaan mengalami fluktuasi yang searah dan positif.

Melihat dari kondisi tersebut diatas dimana kondisi dari perusahaan sangat berfluktuatif maka penelitian ini bertujuan untuk menganalisis pengaruh dari struktur modal dan ukuran perusahaan terhadap tingkat profitabilitas perusahaan.

\section{Profitabilitas}

Profitabilitas merupakan kemampuan dalam memperoleh laba yang dapat diukur dengan menggunakan persentase dimana dipakai untuk menilai sejauh mana perusahaan dapat menghasilkan keuntungan (Mudawamah et al., 2018). Profitabilitas mempunyai arti penting dalam usaha mempertahankan kelangsungan hidup suatu perusahaan dalam jangka panjang, karena profitabilitas menunjukkan apakah perusahaan tersebut dapat mempunyai prospek yang baik di masa yang akan datang (Niresh \& Velnampy, 2014). Dengan demikian setiap perusahaan akan selalu berusaha untuk meningkatkan profitabilitasnya, karena semakin tinggi tingkat profitabilitas suatu perusahaan maka kelangsungan hidup perusahaan tersebut akan lebih terjamin (Aydın Unal et al., 2017).

Hasil pengukuran profitabilitas dapat dijadikan sebagai alat evaluasi kinerja manajemen selama ini, apakah mereka sudah bekerja secara efektif atau tidak (Kasmir, 2014). Kegagalan atau keberhasilan dapat dijadikan bahan acuan untuk perencanaan perolehan laba ke depan (Pranata, 2014). Oleh karena itu, profitabilitas ini juga sering dikatakan sebagai salah satu alat ukur kinerja manajemen (Sulastri \& Zannati, 2018). Beberapa indicator yang dapat digunakan untuk mengukur profitabilitas diantaranya adalah Gross Profit Margin, Operating Profit Margin, Net Profit Margin, Return on Investment, Return on Equity, Return on Common Stock Equity, Earning Per Share, dan Basic Earning Power (Kasmir, 2014). Adapun alat ukur yang digunakan pada dalam menilai profitabilitas perusahaan adalah ROA (Return on Asset) karena alat ukur ini lebih focus pada kemampuan manajemen perusahaan dalam menghasilkan income dari pengelolaan asset perusahaan yang dimiliki (Aydın Unal et al., 2017). ROA (Return on Asset) merupakan pengukuran kemampuan perusahaan secara keseluruhan dalam menghasilkan keuntungan dengan jumlah keseluruhan aktiva yang tersedia di dalam perusahaan (Yusbardini \& Rashid, 2019). ROA dapat dihitung dengan menggunakan rumus sebagai berikut. ROA $=\underline{\text { Laba Bersih sesudah Pajak }} \times 100 \%$

\section{Total Aktiva}

ROA merupakan rasio yang terpenting di antara rasio profitabilitas yang ada (Maryanti, 2016). ROA 
dapat digunakan sebagai alat ukur tingkat kesehatan kinerja keuangan sebuah perusahaan (Kasmir, 2012) karena ROA dapat menunjukkan seberapa baik suatu perusahaan mengendalikan biaya dan memanfaatkan sumber daya yang dimiliki untuk memperoleh keuntungan (Lawrence J. Gitman, 2015).

\section{Ukuran Perusahaan}

Undang-undang RI No. 20 Tahun 2008, mengklasifikasikan ukuran perusahaan ke dalam empat kategori yaitu usaha mikro, usaha kecil, usaha menengah, dan usaha besar. Penggolongan klasifikasi tersebut berdasarkan pada total asset yang dimiliki dan jumlah total penjualan tahunan perusahaan tersebut. Sedangkan keputusan Ketua Bapepam Nomor: Kep.11/PM/1997 menyebutkan bahwa perusahaan kecil dan menengah berdasarkan aktiva (kekayaan) adalah badan hukum yang memiliki total aktiva tidak lebih dari seratus miliar, sedangkan perusahaan besar adalah badan hukum yang total aktivanya diatas seratus miliar. Ukuran Perusahaan merupakan nilai yang menunjukkan besar atau kecilnya perusahaan (Bernardin \& Tifani, 2019). Ukuran Perusahaan juga dapat diukur oleh total asset perusahaan (Aydın Unal et al., 2017). Secara umum teori dari ukuran perusahaan adalah besar kecilnya perusahaan dilihat dari nilai equity, nilai penjualan atau nilai aktiva (Astuti, 2019). Perusahaan besar yang sudah well established akan lebih mudah memperoleh modal di pasar modal dibandingkan dengan perusahaan kecil (Maretha, 2016). Karena kemudahan akses tersebut berarti perusahaan besar memiliki fleksibilitas yang lebih besar.

Pengukuran terhadap ukuran suatu perusahaan dapat digambarkan dengan total asset perusahaan tersebut (Maha Dewi \& Sudiartha, 2017). Semakin besar asset biasanya perusahaan tersebut semakin besar (Skokan et al., 2013). Kenyataannya ukuran aktiva digunakan sebagai alat ukur besarnya perusahaan, ukuran aktiva tersebut diukur sebagai logaritma dari total aktiva (Hartono, 2013). Namun demikian dijelaskan lebih dalam bahwa ukuran perusahaan merupakan suatu skala dimana diklasifikasi besar kecilnya perusahaan menurut berbagai cara seperti total aktiva, log size, dan nilai pasar saham (Suryandani, 2018). Terkait ukuran perusahaan digunakan pengukuran secara umum yang digunakan perusahaan, dimana dapat dirumuskan sebagai berikut (Hartono, 2013).

\section{Ukuran Perusahaan $=$ Ln $($ Total Asset $)$}

Ukuran Perusahaan dihitung dengan menggunakan Logaritma natural dari total asset (Astuti, 2019). Hal ini dikarenakan besarnya total aktiva masing-masing perusahaan berbeda bahkan mempunyai selisih yang sangat besar, sehingga dapat menyebabkan nilai yang ekstrim, untuk menghindari data yang tidak normal tersebut maka total asset perlu dilogaritmakan yang diperoleh dari nilai di posisi laporan keuangan.

\section{Struktur Modal}

Struktur Modal merupakan proporsi keuangan antara utang jangka pendek, utang jangka panjang dan modal sendiri untuk menjalankan aktivitas perusahaan (Vinasithamby, 2015). Pada prinsipnya komponen struktur modal tersusun atas modal asing dan modal sendiri (Maryanti, 2016) Untuk modal asing bisa berupa hutang jangka pendek, hutang jangka menengah, hutang jangka panjang, sedangkan modal sendiri bisa dibedakan menjadi modal saham, cadangan laba, laba ditahan. (Maretha, 2016).

Rasio dari struktur modal terdiri dari Total Debt to Total Assets Ratio (DAR), Total Debt to Equity Ratio (DER), Long Term Debt to Equity (LDER) (Sjahrial, 2013). Adapun alat ukur yang dipakai dalam penelitian kali ini adalah DAR yang dapat dihitung dengan menggunakan formula sebagai berikut.

$$
\mathrm{DAR}=\underset{\text { Total Aktiva }}{\text { Total Utang }} \times 100 \%
$$

Ratio ini digunakan untuk mengukur seberapa besar jumlah aktiva perusahaan yang dibiayai dengan utang. Semakin tinggi rasio ini, berarti semakin besar jumlah modal pinjaman yang digunakan untuk investasi pada aktiva guna menghasilkan keuntungan bagi perusahaan.

\section{METODE PENELITIAN}

Penelitian pengaruh DAR dan ukuran perusahaan terhadap ROA perusahaan yang terdaftar di LQ45 pada Bursa Efek Indonesia, menggunakan metode regresi linier sederhana menggunakan SPSS 20. ROA merupakan variabel terikat dengan DAR dan ukuran perusahaan sebagai variabel bebas. Penelitiannya dilakukan pada 2013-2017, dengan menggunakan metode sampel jenuh dari perusahaan yang terdaftar di LQ45 pada Bursa Efek Indonesia, dengan kriteria aktif dan memiliki laporan keuangan yang lengkap selama lima tahun berturut-turut di LQ45, sehingga diperoleh sampel sebanyak dua puluh tiga perusahaan. Adapun kerangka penelitiannya adalah sebagai berikut. 


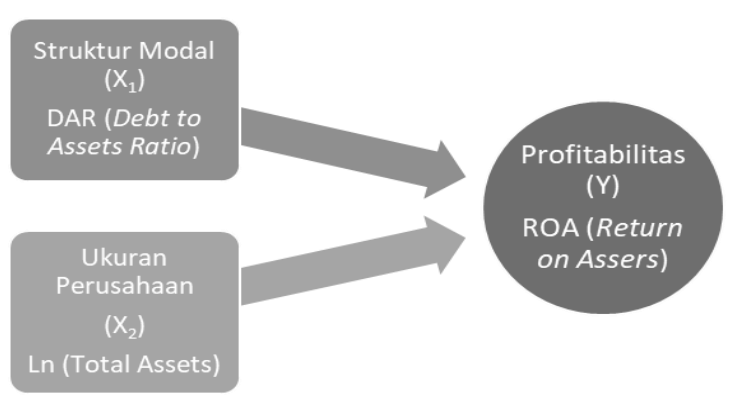

Sumber: (Dewa Kadek Oka Kusuma Jaya, 2014; Man Ying Kang \& Ausloos, 2017)

\section{Gambar 1. Kerangka Pemikiran Penelitian}

Menurut penelitian yang dilakukan terhadap perusahaan yang terdaftar di China pada tahun 2017 ditemukan bahwa struktur modal secara signifikan berhubungan positif terhadap profitabilitas perusahaan (Man Ying Kang \& Ausloos, 2017). Demikian juga halnya dengan penelitian yang dibuat pada tahun 2011 yang dilakukan terhadap perusahaan manufaktur di BEI dimana diketahui bahwa struktur modal yang diukur dengan DER berpengaruh positif dan signifikan terhadap profitabilitas (Dewa Kadek Oka Kusuma Jaya, 2014). Maka dapat dibuat :

Hipotesis 1. Struktur Modal berpengaruh positif dan signifikan terhadap Profitabilitas Perusahaan.

Sedangkan berdasarkan penelitian yang dilakukan pada tahun 2013 pada perusahaan perbankan yang terdaftar di BEI didapatkan hasil penelitian bahwa ukuran perusahaan berpengaruh positif terhadap laba (Wildham Bestivano, 2013). Juga penelitian pada tahun 2012 yang dilakukan terhadap perusahaan food and beverages yang terdaftar di BEI di temukan bahwa ukuran perusahaan berpengaruh positif pada laba (Astuti, 2019), maka dapat dibuat :

Hipotesis 2. Ukuran Perusahaan berpengaruh positif dan signifikan terhadap Profitabilitas perusahaan

\section{HASIL DAN PEMBAHASAN}

\section{Uji Normalitas}

Hasil pengolahan data pertama nampak diketahui dari nilai Kolmogorof-Smirnov sebesar 0.937 dengan tingkat signifikansi sebesar 0.343. Karena nilai signifikan lebih besar dari 0,05 $(\operatorname{sig}>\alpha)$, maka $\mathrm{H}_{0}$ diterima dan $\mathrm{Ha}$ ditolak yang artinya residual terdistribusi normal atau residual berdistribusi normal. Asumsi normalitas untuk model regresi dengan variabel ROA terpenuhi.

\section{Uji Multikolonieritas dan Autokorelasi}

Selanjutnya, hasil pada olah data diketahui pula nilai VIF pada Collinearity Statistics untuk Struktur Modal adalah 1.235 dan nilai VIF untuk Ukuran Perusahaan adalah 1.235. Berdasarkan kriteria pengujian multikolonieritas, dapat disimpulkan bahwa diantara variabel independen tidak terjadi multikolonieritas karena nilai dari VIF $<10$ atau dengan kata lain dapat disebut tidak terjadi gangguan atau terbebas dari gejala multikolonieritas. Berdasarkan pengolahan data melalui SPSS menunjukkan bahwa nilai Durbin-Watson (DW) sebesar 1.837, maka dapat disimpulkan bahwa Tidak Terjadi Autokorelasi dalam data penelitian ini.

3. Uji Regresi Linier Berganda

Tabel 1. Uji Regresi Linier Berganda

\begin{tabular}{|c|c|c|c|c|c|}
\hline \multirow{2}{*}{ Model } & \multicolumn{2}{|c|}{$\begin{array}{c}\text { Unstandardized } \\
\text { Coefficients }\end{array}$} & $\begin{array}{c}\text { Standardized } \\
\text { Coefficients }\end{array}$ & $\mathrm{t}$ & Sig. \\
\cline { 2 - 6 } & $\mathrm{B}$ & Std.Error & Beta & & \\
\hline (Constant) & -1.757 & .153 & & -11.475 & .000 \\
Struktur Modal & .005 & .001 & .176 & 3.409 & .001 \\
Ukuran Perusahaan & .124 & .008 & .773 & 14.983 & .000 \\
\hline
\end{tabular}

Sumber: Olahan Data (SPSS), 2019

Berdasarkan Tabel 1 dapat diketahui bahwa model regresi linear tersebut dapat dianalisis berdasarkan koefisien-koefisiennya. Model persamaan regresi linear berganda berdasarkan tabel di atas adalah:

$$
Y=-1.757+0.005 X_{1}+0.124 X_{2}
$$

Profitabilitas $=-1.757+0.005($ Struktur Modal $)+$ 0.124 (Ukuran Perusahaan)

Hasil dari penelitian diperoleh variabel Struktur Modal $\left(\mathrm{X}_{1}\right)$ berpengaruh secara positif dan signifikan terhadap Profitabilitas (Y), karena signifikansinya 0.001 yaitu lebih kecil dari 0.05 , atau dapat dikatakan bahwa variabel Profitabilitas 
dipengaruhi oleh Struktur Modal. Jadi hipotesis yang menyatakan bahwa rasio Struktur Modal berpengaruh positif dan signifikan terhadap Profitabilitas dapat diterima. Variabel Ukuran Perusahaan juga berpengaruh secara positif dan signifikan terhadap Profitabilitas karena signifikansinya sebesar 0.000 lebih kecil dari 0.05 atau dapat dikatakan juga ukuran Perusahaan berpengaruh positif dan signifikan terhadap Profitabilitas. Dari uji ANOVA atau F test didapat $\mathrm{F}$ hitung sebesar 118.278 dengan probabilitas 0.000 . Karena probabilitas jauh lebih kecil dari 0.05 maka model regresi dapat digunakan untuk memprediksi Profitabilitas atau dapat dikatakan bahwa Struktur Modal dan Ukuran Perusahaan secara bersama-sama (simultan) berpengaruh signifikat terhadap Profitabilitas. Hasil dari penelitian ini menunjukkan bahwa adjusted R square sebesar 0,506. Hal ini menunjukkan bahwa Profitabilitas di pengaruhi oleh Struktur Modal dan Ukuran Perusahaan sebesar $50.6 \%$ dan $49.40 \%$ dipengaruhi oleh variabel lainnya yang tidak dimasukkan ke dalam model.

Struktur Modal secara parsial berpengaruh positif dan signifikan terhadap Profitabilitas perusahaan. Hasil penelitian (San, O.T. \& Heng, 2011), mendukung hasil penelitian pada uji hipotesis pertama. Namun, peneltian ni tidak sesuai dengan penelitian (Halim, 2009) yang mengungkapkan bahwa perusahaan yang mempunyai tingkat keuntungan yang tinggi justru mempunyai tingkat hutang yang lebih kecil. Nilai positif pada koefisien menunjukkan jika struktur modal naik satu satuan maka diestimasikan profitabilitas naik sebesar 0.005 satuan. Hal ini menandakan hutang yang dimiliki perusahaan dalam sampel penelitian ini cukup kecil yang mengakibatkan resiko yang ditanggung juga kecil. Resiko kecil yang ditanggung perusahaan ditutupi oleh laba bersih yang dihasilkan, sehingga nilai Profitabilitas kecil dikarenakan hutang yang kecil tersebut.

Hasil penelitian menunjukkan bahwa ukuran perusahaan berpengaruh positif dan signifikan terhadap profitabilitas. Hal ini dikarenakan objek perusahaan yang diteliti adalah perusahaan yang terdaftar di LQ 45 Bursa Efek Indonesia yang pada periode penelitian yaitu Periode 2013-2017, memang dalam kondisi stabil, maka hal tersebut akan berpengaruh juga terhadap ukuran perusahaan karena ukuran perusahaan berbanding lurus dengan profitabilitas. Namun hasil penelitian (Ayu \& Setiadewi, 2012) mengungkapkan bahwa ukuran perusahaan berpengaruh tidak signifikan terhadap profitabilitas.

\section{KESIMPULAN}

Struktur Modal berpengaruh positif secara parsial terhadap Profitabilitas pada 23 perusahaan aktif periode 2013-2017 yang terdaftar di LQ 45 Bursa Efek Indonesia, hal tersebut tergambar dalam hasil uji hipotesis, juga dari Hasil Uji Regresi Linier Berganda. Dengan kata lain, peningkatan DAR akan berpengaruh terhadap peningkatan Profitabilitas. Ukuran perusahaan berpengaruh positif secara parsial terhadap Profitabilitas pada 23 perusahaan aktif periode 2013-2017 yang terdaftar di LQ 45 Bursa Efek Indonesia, hal ini karena memang perusahaanperusahaan tersebut dalam kondisi stabil, maka hal ini akan berpengaruh juga terhadap ukuran perusahaan karena ukuran perusahaan berbanding lurus dengan profitabilitas. Struktur Modal dan Ukuran Perusahaan berpengaruh secara simultan terhadap Profitabilitas pada 23 perusahaan aktif periode 2013-2017 yang terdaftar di LQ 45 Bursa Efek Indonesia.

Pengukuran variabel Struktur Modal dalam penelitian ini adalah dengan Debt to Assets Ratio (DAR), Ukuran Perusahaan menggunakan Ln of Total Asset sedangkan variabel Profitabilitas menggunakan Return on Assets (ROA). Untuk penelitian selanjutnya, dapat menggunakan pengukuran yang berbeda untuk mengukur pengaruh Struktur Modal dan Ukuran Perusahaan terhadap Profitabilitas. Pada penelitian ini juga hanya menggunakan perusahaan yang terdaftar pada LQ45 yaitu sebanya 23 perusahaan. Saran untuk peneliti selanjutnya yaitu dengan memperluas perusahaan yang dijadikan bahan penelitian seperti misalnya keseluruhan perusahaan yang terdaftar di Bursa Efek Indonesia. Dan untuk tahun penelitian sebaiknya menggunakan data tahun terbaru dan diperbanyak.

Dalam penelitian ini hanya digunakan variabel DAR untuk struktur modal, Ln Asset untuk ukuran perusahaan dan ROA untuk profitabilitas. Untuk penelitian selanjutnya, dapat menggunakan pengukuran yang berbeda untuk mengukur pengaruh antara struktur modal, ukuran perusahaan juga profitabilitas diantaranya yaitu menggunakan Debt to Equity Ratio (DER), Total Asset Turn Over (TATO), sales growth dan lainnya. Diharapkan ada penelitian selanjutnya yang dilakukan pada perusahaan dengan jenis yang lebih spesifik untuk bidang usaha tertentu dengan periode yang lebih baru sehingga dapat memberikan informasi yang dibutuhkan bagi investor maupun pengusaha untuk dapat memprediksi dan memaksimalkan profitabilitas dari perusahaannya

\section{REFERENSI}

Amelia, F., Anhar, M., Perusahaan, N., Perusahaan, N., Modal, S., Perusahaan, P., Ratio, E., Aktiva, P. T., Equity, R. O., \& Jalur, A. (2019). Pengaruh Struktur Modal Dan Pertumbuhan. 28(01), 44-70.

Astuti, D. W. (2019). Pengaruh Profitabilitas , Leverage Dan Ukuran Perusahaan Terhadap Luas Pengungkapan Tanggung Jawab Sosial. Jurnal Ilmu Dan Riset Akuntansi, 5(2), 1-18. https://doi.org/10.26460/AD.V3I2.5287

Aydın Unal, E., Unal, Y., \& Isık, O. (2017). the Effect of Firm Size on Profitability: Evidence From 
Turkish Manufacturing Sector. Pressacademia, 6(4), 301-308. https://doi.org/10.17261/pressacademia.2017.7 62

Ayu, K., \& Setiadewi, Y. (2012). PENGARUH UKURAN PERUSAHAAN DAN LEVERAGE Fakultas Ekonomi dan Bisnis Universitas Udayana, Bali , Indonesia dengan Herawati ( 2012 ) yang membuktikan profitabilitas secara signifikan. Pengaruh, 596609.

Bernardin, D. E. Y., \& Tifani, T. (2019). Financial Distress Predicted By Cash Flow and Leverage With Capital Intensity As Moderating. Jurnal Apresiasi Ekonomi, 7(1), 18-29. https://doi.org/10.31846/jae.v7i1.188

Dewa Kadek Oka Kusuma Jaya. (2014). PENGARUH STRUKTUR MODAL , PERTUMBUHAN PERUSAHAAN DAN PROFITABILITAS TERHADAP NILAI PERUSAHAAN PADA. 2.

Dewi, M. A. P., \& Candradewi, M. R. (2018). Pengaruh Pertumbuhan Perusahaan Dan Profitabilitas Terhadap Struktur Modal Dan Nilai Perusahaan. E-Jurnal Manajemen Universitas Udayana, 7(8), 4385. https://doi.org/10.24843/EJMUNUD.2018.v07 .i08.p13

Gill, A., Biger, N., \& Mathur, N. (2011). The Effect of Capital Structure on Profitability: Evidence from the United States. International Journal of Management, 28(4), 3-15.

Halim, A. dan M. M. H. (2009). Analisis Laporan Keuangan (4th ed.). UPP STIM YKPN. Yogyakarta.

Hartono, J. (2013). Teori Portfolio dan Analisis Investasi. BPFE, Yogyakarta.

Jaenudin, \& Jeni. (2012). Analisis Pengaruh Rasio Profitabilitas Terhadap Harga Saham Pada Perusahaan Lq45 Di Bursa Efek Indonesia (Bei).

Kartikasari, D., \& Merianti, M. (2016). The effect of leverage and firm size to profitability of public manufacturing companies in Indonesia. International Journal of Economics and Financial Issues, 6(2), 409-413.

Kasmir. (2012). Analisis Laporan Keuangan. PT. RajaGrafindo Persada, Jakarta.

Kasmir. (2014). Bank dan Lembaga Keuangan Lainnya (14th ed.). PT. RajaGrafindo Persada, Jakarta.

Lawrence J. Gitman. (2015). Principles of Managerial Finance (14 th edit). Chad J. Zutter, University of Pittsburg.

Maha Dewi, D., \& Sudiartha, G. (2017). Pengaruh Profitabilitas, Ukuran Perusahaan, Dan Pertumbuhan Aset Terhadap Struktur Modal Dan Nilai Perusahaan. E-Jurnal Manajemen Universitas Udayana, 6(4), 2222-2252.

Man Ying Kang, \& Ausloos, M. (2017). An Inverse
Problem Study: Credit Risk Ratings as a Determinant of Corporate Governance and Capital Structure in Emerging Markets: Evidence from. https://doi.org/10.3390/economies5040047

Maretha, R. (2016). Pengaruh Ukuran Perusahaan Dan Debt To Equity Ratio Terhadap Nilai Perusahaan. 2010, 101-102.

Maryanti, E. (2016). ANALISIS PROFITABILITAS, PERTUMBUHAN PERUSAHAAN, PERTUMBUHAN PENJUALAN DAN STRUKTUR AKTIVA TERHADAP STRUKTUR MODAL PADA PERUSAHAAN SEKTOR INDUSTRI BARANG KONSUMSI YANG TERDAFTAR DI BURSA EFEK INDONESIA (Studi Empiris Pada Perusahaan Manufaktur yang Terdaf. Riset Akuntansi Dan Keuangan Indonesia, $\quad 1(2), \quad 143-151$. https://doi.org/10.23917/reaksi.v1i2.2730

Mudawamah, S., Wijono, T., \& Hidayat, R. R. (2018). ANALISIS RASIO KEUANGAN UNTUK MENILAI KINERJA KEUANGAN PERUSAHAAN (Studi pada Bank Usaha Milik Negara yang Terdaftar di Bursa Efek Indonesia Tahun 2013-2015). Jurnal Akuntansi Bisnis, 54(1), 20-29.

Niresh, J. A., \& Velnampy, T. (2014). Firm Size and Profitability: A Study of Listed Manufacturing Firms ed Manufacturing Firms in Sri Lanka. International Journal of Business and Management, 9(4), 57-64. https://doi.org/10.5539/ijbm.v9n4p57

Pervan, M. (2012). Influence of Firm Size on Its Business Success. Croatian Operational Research Review, 3(1), 213-223.

Pongrangga, R. (2015). PENGARUH CURRENT RATIO, TOTAL ASSET TURNOVER DAN DEBT TO EQUITY RATIO TERHADAP RETURN ON EQUITY (Studi pada Perusahaan Sub Sektor Property dan Real Estate yang Terdaftar di BEI periode 20112014). Jurnal Administrasi Bisnis S1 Universitas Brawijaya, 25(2), 86188.

Pranata, D. (2014). PENGARUH TOTAL ASSET TURNOVER, NON PERFORMING LOAN, DAN NET PROFIT MARGIN TERHADAP RETURN ON ASSET (Studi pada Bank Umum Swasta Devisa yang terdaftar di Bank Indonesia tahun 2010-2012). Jurnal Administrasi Bisnis S1 Universitas Brawijaya, 11(1), 82321.

Rahimian, M. (2016). The Relationship between Capital Structure and Profitability of Companies Listed in Tehran Stock Exchange. European Online Journal of Natural and Social Sciences, 5(1), 128-131.

Riyadi, S. (2018). Analisis Resiko Keuangan Pada Perusahaan Manufaktur Yang terdaftar di Bursa Efek Indonesia Analysis Of Financial Risk In Manufacturing Companies Listed In 
Indonesia Stock Exchange. Sinar Manajemen, 5(2), 74-81.

San, O.T. \& Heng, T. . (2011). No Title. Capital Structure and Corporate Performance of Malaysian Construction Sector, International Journal of Humanities and Social Science, 1(2): 28-36.

Sjahrial, D. dan D. P. (2013). Analisis Laporan Keuangan. Jakarta: Mitra Wacana Media.

Skokan, K., Pawliczek, A., \& Piszczur, R. (2013). Strategic Planning and Business Performance of Micro, Small and Medium-Sized Enterprises. Journal of Competitiveness, 5(4), 57-72. https://doi.org/10.7441/joc.2013.04.04

Sulastri, E., \& Zannati, R. (2018). Prediksi financial distress dalam mengukur kinerja perusahaan manufaktur. Jurnal Manajemen Strategi Dan Aplikasi Bisnis, 1(1), 27-36. https://doi.org/10.36407/jmsab.v1i1.17

Supardi, H., H. Suratno, H. S., \& Suyanto, S. (2018). Pengaruh Current Ratio, Debt To Asset Ratio, Total Asset Turnover Dan Inflasi Terhadap Return on Asset. JIAFE (Jurnal Ilmiah Akuntansi Fakultas Ekonomi), 2(2), 16-27. https://doi.org/10.34204/jiafe.v2i2.541
Suryandani, A. (2018). Pengaruh Pertumbuhan Perusahaan, Ukuran Perusahaan, Dan Keputusan Investasi Terhadap Nilai Perusahaan Pada Perusahaan Sektor Property Dan Real Estate Di Bei. BMAJ: Business Management Analysis Journal, 1(1), 49-59. https://doi.org/10.24176/bmaj.v1i1.2682

Vinasithamby, S. (2015). Firm Size Influence on Profitability of Sri Lankan Diversified Holdings Firms. International Journal of Advanced Research in Management and Social Sciences, 6(6), 201-207.

Wildham Bestivano. (2013). "pengaruh ukuran perusahaan, umur perusahaan, profitabilitas, dan.

Yusbardini, Y., \& Rashid, R. (2019). Prediksi Financial Distress Dengan Pendekatan Altman Pada Perusahaan Manufaktur Di Indonesia. Jurnal Muara Ilmu Ekonomi Dan Bisnis, 3(1), 122. https://doi.org/10.24912/jmieb.v3i1.3543 